\title{
Sweetness of Gitanjali
}

DOI: https://doi.org/10.47175/rielsj.v2i2.259

\section{| Rahmatullah Hakimi |}

Paktika University, Education Faculty, Pashto Department, Paktika, Afghanistan

rahmatullahhakime@gmail.com

\begin{abstract}
Literal language talks in a higher level than common language, everyone doesn't have the ability to speak on literal language. There is a question that how to speak on uncommonly speaking, this uncommon speaking is the highest quality of art. These quality percepts the aesthetic of literature by the reader and Gitanjali is its best example. This master piece is an advice and enjoy. Here are devoted songs which show close relationship between lover and beloved, pain of separation with enjoyment, emotion and clear senses are interpreted with imaginative language, not only individuals but also the whole human being can see their pure love. This master piece of work has attractiveness and artistic. We will discuss both of them here.
\end{abstract}

KEYWORDS

artistic enjoyment, Tagor 's poems, Gitanjali

\section{INTRODUCTION}

Along other works of Rabindranath Tagore, Gitanjali is the best work for two reasons; one its message and other is its way of presenting. This is the reason that Tagore got the crown of world award on his head. That pain and wishes that Tagore had offered to his beloved in an artistic way, which give to reader sense of love, mercy, joy, and beauty. This article discusses the aesthetic and content of Gitanjali to understand readers from his inner world and artistically performance of Tagore.

Gitanjali is a master piece that has special beauty, fullness and integrity. So, the analysis of the content to the book gives power and encouragement to those are analyzing. It informs us from the thoughts and aesthetic work of the writer, philosophy, play write, and poetry of Tagore. It familiarizes us with valuable parts of the master piece. The article will discuss core points of Gitanjali.

Literature familiarizes us with how to say and how to write. In the analysis of this work we will discuss that how Tagore changed how to say to how to write. Here we will study that how he have done has work that became a master piece. Tagore has conveyed a very high quality thoughts in a great way in Gitanjali that Eastern literature will always look up to it and make it look beautiful to all humanity, which is the purpose of this research paper. The study analysis the sweetness in Gitanjali, specifically it answer the questions below:

What message does the Gitanjali have in terms of content?

What is the aesthetic beauty and feature of the Gitanjali?

What are the artistic points here?

How had it become world master piece?

\section{RESEARCH METHODS}

This is a qualitative research which will focus on discussion and analysis. 


\section{RESULTS AND DISCUSSION}

\section{Content}

Rabindranath Tagore, a Bengali writer from India, is known in the world for his literary genius. He is compared and nominated by different famous figures such as: Roman Lal compared him with Plato of his time, Ehsan nominated him is the pioneer of revolutionary thought in India, Professor Humayun considered him as Shakespeare of the Orient and was given the title of Grand Murshid by the Indians.

He is the author of 163 works. Some Indian poets said: "Tagore came to the land of India as a heavenly prophet. His language was spreading flashes of literary works instead of words. $3: 49$ "

Tagore loves with art; each of his work of art is a unique report of his internal world, emotions and heartfelt tendencies. Eric Newton's words about him come to mind: "So it is true to say that every work of art is like a child who is a mother to the artist, and the environment of the life of the artist is his father. In this metaphor, we engage and enjoy the art, get the status of uncles and aunts... the artists who have created these works of art are our brothers and sisters." $6: 85$

Newton pointed that every work of art is like a child to Tagore, whose artist is his mother (Tagore), whose artist's environment (Tagore's environment) is his father. We enjoy that have relationships aunts and uncles with them. The artists who have created such works are our brothers and sisters. Among other works, Tagore's (Gitanjali) poems have wonderful artistic and pleasure. I don't know what will be my analysis about them. Sometimes a sentence, whether it is a poem or a prose, is sweet to me, it always stays in my heart, sometimes I understand its cause and sometimes I read it again and again, I enjoy reading it, but I don't understand it easily, because there are different aesthetics. I wonder what beauty I have buried in my heart, which I am unable to interpret, and I cannot imagine this taste after so much to percept it, I will never forget it again. This is how I am treated while reading Tagore's writings. I have read the Gitanjali again and again, every time I read it, a new perception appeared to me. I want to share the beauty of this perception with you what I have felt. What are the different variants? What is the cause of it? Why does it go to the depth of heart and our feelings and emotions awaken with it?

The answer to these questions requires a different torment; I will only answer you with the impression taken from the effect of the book.

\section{Content Review of Gitanjali}

Gaitanjali is a masterpiece of Tagor which won the Nobel Prize. The English translation of this work was done by Tagore himself, the Urdu translation by Niaz Fatehpuri, the Persian translation by Rawan Farhadi, and the Pashto translation by Abdul Rauf Benawa. Let me talk about the third edition of the work translated by Benawa, which consists of all (103) poems.

Gitanjali is Tagore's masterpiece, written in 1910 about the death of his mother (Marinletti Devi), his second daughter in 1904 AD and his father, Devendra Nath, Tagore left this world forever in 1905 A.D. His eldest son died in the year 1907 A.D. These are the pains that interpret the inner world of Tagor. Allama Iqbal has said: "a slight pain of a heart is greater than the sapience of Plato, the glory of Dara and the arrogance of Feridun." 175:5 
It was these pains and sorrows that Tagore sacrificed to his beloved. These poems are not only exploring the inner world of an individual but also transcend humanistic boundaries, offering the burning cry of eternal love and beauty, separation to all humanity.

In terms of content, Gitanjali is a song of pain, love and beauty that is dedicated to its creator. He brought death as a nice beloved in front of our eyes. Most of Gitanjali's poems are secret with God which are as praised ones that have a great beauty of author's beloved. Karwan mentioned: "Sometimes in Gitanjali we see a poor girl, who is facing the king. This facing becomes a poetic and musical tableau of beauty and glory. The king's beauty and love picture is a metaphor for Great lord. In many of his poems, Tagore stands by the poor and the needy, telling them that the Almighty God is with you the most." 83:2

To illustrate the point, we quote a few sentences from poem 35: "Leave me only a small part of it, in which my each part have respect for you, leave me such a small part of my desire, in which I can feel you everywhere. In which I will find you everything, and every moment; I will offer my love to you. Leave me only a small part. Just leave me in your chain to obey your will and fulfil your purpose in my life, yes! This is your love chain. 16: 2

Although there are traces of Hindu philosophy in Tagore's poems, most of the issues related to humanity have been turned into art. We see in the above sentences that high love is interpreted emotionally, with love and complete satisfaction and shared heartfelt with beloved.

Another great message in Tagore's poems is that time is valued and protection from the moment of neglect. Tagore is bothered that negligence moments had not built a wall between me and my beloved. In poem 26, he said: "he came, seated beside me, but I did not awake. $\mathrm{Oh}, \mathrm{I}$ was what a miserable dream!" 2:12

Elsewhere, some of the verses of poem 47 are devoted to the interpretation of this sweet and painful feeling: "The night has passed in useless waiting for him; I am afraid that a morning he will come to my door and I will be exhausted, and asleep in the sleep of negligence. Oh friends! Leave him, do not stop him, if his footsteps sound does not wake me up, do not try to wake me up." 2:22

In short, Tagore's poems enchant human on life, death, the universe and the Creator, and are a song of relief to the human heart.

\section{6-2 The Artistic and Beautiful Discussion of poems of the Gitanjali}

The beauty of this work is that it gives the reader more and more interest at each time you are reading it. Every word of it falls in hearts forever. Expressing the words that touch the heart is not an easy task.

\section{6-2-1 . Gitanjali’s Poems have Emotional Sweetness:}

The poetry of Gitanjali has inspirational emotion, which gives a band of spiritual relief and joy to every pain and hurt heart. It is aesthetical item (emotion) that has given a strange tune to Tagore's poetry, because emotion is the natural beautification of a work beyond artificial jewelry, and love originates from the heart, the sound of the heart has a very spiritual weight, according to Ulfat, it affects the souls. The Gitanjali poems are emotionally unique, because their themes are watered down with love, affection and pain. The late Ulfat wrote about the appearance of emotions, "There are some issues in which emotions lighten as flashes of fire, 
such as patriotism, love, sorrow, and so on; but there are some other themes, such as philosophical thoughts and social ideas are cold.1:97"

So, the offering of Tagore's poems are thematically images of pain and love, which is full of painful emotional sighs, which has given a special aesthetical effect, to prove the claim, we will analyze one or more poems.

In poem 35, I was shocked when I saw a sentence: "Leave with me only a small part of it, in which I have honor for you." Now let's look at the answer to the question, why did it affect me? I saw in the above sentence the unlimited love, the sacred connection between the Creator and the creature, the faith and the hope. The above sentence is the Pashto translation of a poem: (Leaving a small part in the body) (Oh! my everything!) And (I call you) those are all parts that provoke the emotional power. When we say (Oh! my everything!) That we are disconnected from all other things and people, only the sacred connection of hope and faith with our beloved is realized, so there must be such a relationship with the Creator that Rabindranath Tagore has created connection of faith. And he loves his beloved so much that even the smallest part of his body can remember and call him. Elsewhere, in (41) poem, the compassion, love and affection of his beloved and Creator are so immeasurable: (18: 2) "your mercy and love's cloud tend below as mother's face that look down with eyes full of tears when father is shouting on her and sulky." This sentence is also emotionally sweet. We humans are often disobedient to our Creator, yet we do not turn a blind eye from His mercy.

Tagore invites human to love, beautifies even the terrifying creature of death look beautiful to him like and treats him emotionally as beloved, as he said in (91) hymn: What will you offer him? What will you give when death comes to you? Oh, I will offer my guest a full cup of my life, I will never leave him empty-handed. 2:47

Philosophically death is the second name of life. If there were no death, we would not know the name of life, but life is sweet and death is bitter. Tagore also beautified the bitter reality of death, invited her as his guest and gave her his sweet life for the happiness of his beloved. It seems that the boundary of life and death cannot turn Tagore away from love and affection.

He loves his beloved to such a way that he feels her with heart and treats her lovely and emotionally, as in poem (60) which said: My heart tended down to my footsteps and my heart kisses your footsteps. 2:30" These words of Tagore reminded me of some sentences from our famous writer Ishaq Nangyal's novel Shadow, he also tasted the same kind of fun, there it is written:" ( It is my turn to follow the path and cultivate, grow and spread but if passenger come, step over on me and finish me, I know her foot, it does not come on me to cross me." 7:50

The sentences of both writers are made of loving emotional pain, with a kind of taste. This part of Tagore's sentence (My heart kisses your footsteps) and this part of Nangyal's sentence (But I know her foot, it does not come on me to cross me) have obvious difference, only with the difference that the real love is deepen in Tagore's sentence. The power of love is great. Tagore's words are full of emotional sensation; these beautiful things on the one hand give a special artistic joy. "Tagore's poems have broken my beauty," said one tourist, who was an example of high beauty.

6-2-2 Gaitanjali poems have sensory phrases and words: There are a lot of sensory words in Tagore's poems, through which spiritual feelings are conveyed, sentences are addressed to 
the senses and the senses are activated. Ustad Ghazanfar writes about sensory words: Sensory words address the senses, say something to the senses. 4:14

Whatever is done against our senses, or has been done, brings with it our spiritual relief. The reason is that we have mastered the senses and saved us from abstract conflicts. Rabindranath Tagore addresses a situation instead of say something and stimulate or activate senses. This aspect is another sweetness of his words; a few sentences will bring her to give as an example:

1."If you do not speak to me, I will fill my heart with silence." (20 poem)

The above sentence refers to the sense of sight. Silence has no physical structure, thought how it will fill something, but Tagore gives a materialistic existence to the spiritual being of silence and draws our attention to it. And the sense of sight draws our attention to it, in the literature making this kind of speech makes it unusual and pushing it to the border of arts.

2. The July rain escapes the view of the occupants in the shade of the trees, slowly falling silently like the Torah.

In the above sentence, although the rain is seen, the whole discussion is on the falling in the slow and silent rain, which Tagore calls like the Torah with a silent mouth and the words of the silent mouth address the sense of hearing.

3. My hopes were raised and I thought that now my bad days are over. We see in the above sentence that Tagore raised hopes and addressed the sense of sight.

4. The sea waves with laughter (61poem). The above sentence is fully referred to the sense of hearing, because the noise of the river waves as interpreted with laughter.

5. It is the sorrow of separation that all night one star looks silently at another star, and in the dark rain of July the rain falls among the shaking leaves and makes song ( 85 poem)

In the above sentence we see that the stars look at each other silently, which speaks to the visual sense and is made up of the sound of shaking leaves, which addresses the sense of hearing. Some other examples are as follows: At that time, your words will fly from birds nest to every direction as a song. (20 poem)

We dreamed that there would be a distant thunderstorm will shake the earth and the walls (52 poem) I opened my eyes and saw you; standing next to me and the flood of your smile had brought me to sleep (49 Anthem).

Another feature of sensuality is that it moves abstract concepts and brings them closer to the senses. It speaks to our senses and stimulates our senses. Such as in the above sentences (flood of slime), (flies of speech) and (shaking of walls) are combines: the specialty of these words and sentences is that talk to our senses and gives moment to our senses. It gives life to artistic prose and poetry and gives eternal art. The feature of sensuality is a high feature of contemporary art that has given a special charm and beauty to Tagore's poetry.

\section{6-2-3 The Gaitanjali Poems have Vivid Images:}

Tagore's poems form an album of living pictures. He has painted a beautiful picture in nature, painted a strong picture in accordance with all natural conditions, most of the poems are like that. (85) Anthem is given as an example: "It is the pain of separation, which is spread all over the world, and it is the pain that manifests in innumerable forms in the infinite sky. This is the grief of separation that all night one star see other one silently, and in the dark fog of 
the rain of July makes song on hanging leaves. When this pain of separated become deepen than change on the wishes of love and finds way in human. The pain comes firing tune out from burnt heart of poet."

The stars are saddened for the above words of separation, the leaves are shaken and the poet's heartfelt songs are sung over it. All these situations are the result of separation. Living images add charm, eagerness and sweetness to the word, everything is shown in moment. The reader thinks as that everything is happening right before my eyes. When the reader finds himself in such a situation, he expresses joy and happiness, with which the poem also finds sweetness. All these appears in Tagore's poems, with these images he has created a beautiful picture of love, pain of separation and beautify nature for the Creator, and has made his words naturally beautiful.

The stars above for the word separation are saddened, the leaves are shaken and the poet's heartfelt songs are sung over it. And for all these circumstances, separation has become the subject. Living images add charm, charm and sweetness to the word, everything is shown in it. The reader thinks as if everything is happening right before my eyes. When the reader finds himself in such a situation, he expresses joy and happiness, with which the word also finds sweetness. All this can be seen in Tagore's cold, with these images he has created a beautiful picture of love for the Creator, the sweet pain of separation and nature and has made his words naturally beautiful.

The vivid illustrations and sceneries give Tagore's hymns a special artistic beauty, in which we see images in which the reader feels present and takes a special aesthetics. For example, let us quote the last sentence of Psalm 51: "The clouds roar in the sky. The darkness of the night is shaken by the lightning. You spread your old carpet on the floor. The king of our glorious night suddenly Come with the storm!) (26: 2)"

6-2-4 It has Metaphors and Similes: Tagore used rare metaphors and similes in his poems with which his words are still artistic, like the opening sentence of the poem (80): “... I am wandering in the air like pieces of autumn clouds, O ever-shining sun! I also count the years and months apart from yours." (2: 42) in the above part he compared himself with clouds and metaphorically called his beloved shining sun that emotionally requested mercy and attention. Elsewhere in verse 27, he gives a detailed similarity of night and the black stone: "The night is darker than the black stone. Do not spend your time in this state of darkness lighten the candle of love of your life.

\section{CONCLUSION}

Rabindranath Tagore is a rising star in Eastern literature, who breathed life into all Oriental literature with his scientific genius, literary genius and tasteful tendencies. He wrote countless works that calmed hearts, the Nobel laureate (Gaitanjali) became a world-famous book in the field of literature, translated into many languages. Affection, compassion, heavy messages of glory and beauty are presented in it artistically. Some of the artistic and aesthetic parts that touched my heart, I conveyed to you. In short, Gitanjali is a work full of beauty that carries heavy message of glory and beauty.

\section{REFERENCES}

Ghazafar, Asadullah. (2020). The Art of writing prose, The Afghan Cultural Society in the Netherland.

Ghazafar, Asadullah. (2020). Cheragh, 2nd edition, Momand publishing society, Jalalabad. 
Nangyal, Mohammad Ishag, Seori. (1999). Novel: Danish Library Peshawar

Newton, Aric. (2017). The meaning of beauty, Translated by Parvez Marzban, Eighth printing, Scientific and Cultural writing company.

Rahmani, Gulrahman. (2014). Tagore is the world's most famous writer and magical poet, Sweet Magazine, First number, Kandahar.

Tagore, Rabindranath, (2005). Gitanjali. 3rd edition, Translated by Abdul Rauf Benawa, Cultural Society, Kandahar.

Ulfat, Gulpacha. (1964). Literary discussions , Pashto society, Kabul Afghanistan 